\title{
Research on Breadth and Depth of BIM capabilities
}

\author{
HE Guiyou ${ }^{1, a}$ and BIAN Li ${ }^{2, b}$ \\ ${ }^{1}$ School of Economics and Management, Tongji University, Shanghai, 200092, China. \\ ${ }^{2}$ Shanghai Electric Power Design Institute Co., Ltd., Shanghai, 200025, China \\ aheguiyou@163.com, biangrikuili@163.com
}

Key Words: Building Information Modeling, breadth, depth

Abstract. The definition of BIM was reviewed from two perspectives of tool and process based on the literature from BIM software developers, BIM international research organizations and BIM monographs. The measurement models of the breadth and depth of BIM implementation level were designed based on the existing research findings, which provide a new idea for the measurement of BIM implementation level from the perspective of firm. This paper lays a foundation for the BIM implementation strategy for enterprise and implementation plan for industry.

\section{Introduction}

As slow technology progress, energy consumption and environmental impact, construction industry is criticized. In view of the increasingly problems, construction industry should change the old paradigm of development. Accordingly, paradigm changes the direction of the theory and research. On a global scale, BIM (Building Information Modeling) has been widely regarded as a milestone in the construction industry technology development. BIM is not only the information to change the way of the production and use, but also changes the project organization pattern and the production process. The application of BIM research has certain industry value and strategic significance. Through extensive literature retrieval and analysis, existing BIM research mainly focused on the technical interoperability perspective, few literatures are under the perspective application of BIM technology. Playing an important role in BIM technology adoption and application, it is of great significance to measure construction enterprise of BIM application level. Based on the related research on BIM application, this paper proposed of the breadth and depth of two dimension BIM application measure model.

\section{The definition of BIM}

This definition of Building Information Modeling in the Handbook of BIM encompasses a lot starting from a technology to embracing the whole construction process. Chuck Eastman proposed the concept of BIM in its Building Information model handbook [1]. Although many scholars believe that BIM application still has many obstacles, the academic circles and business have been widely realized BIM application features and potential value. 


\begin{tabular}{|c|c|c|c|c|}
\hline \multirow{2}{*}{\multicolumn{2}{|c|}{ Origin }} & \multirow[t]{2}{*}{ Definition } & \multicolumn{2}{|c|}{$\begin{array}{c}\text { Analysis } \\
\text { Perspective }\end{array}$} \\
\hline & & & Static & Dynamic \\
\hline \multirow{4}{*}{$\begin{array}{l}\text { Related } \\
\text { famous } \\
\text { organization }\end{array}$} & $\begin{array}{l}\text { Associated } \\
\text { General } \\
\text { Contractor }\end{array}$ & $\begin{array}{l}\text { Building Information Modeling is the development and use of a } \\
\text { computer software model to simulate the construction and } \\
\text { operation of a facility. The resulting model, a Building } \\
\text { Information Model, is a data-rich, object-oriented, } \\
\text { intelligent and parametric digital representation of the } \\
\text { fofc Amitri,cafrom which views and data appropriate to various } \\
\text { users' needs can be extracted and analyzed to generate } \\
\text { information that can be used to make decisions and improve the } \\
\text { process of delivering the facility [2]. }\end{array}$ & $\sqrt{ }$ & $\sqrt{ }$ \\
\hline & $\begin{array}{l}\text { National } \\
\text { Institute } \\
\text { of } \\
\text { Building } \\
\text { Sciences }\end{array}$ & $\begin{array}{l}\text { A Building Information Model is a digital representation of } \\
\text { physical and functional characteristics of a facility. As } \\
\text { such it serves as a shared knowledge resource for information } \\
\text { about a facility forming a reliable basis for decisions during } \\
\text { its life-cycle from inception onward [3]. }\end{array}$ & $\sqrt{ }$ & $\sqrt{ }$ \\
\hline & ISO & $\begin{array}{l}\text { A Building Information Model (BIM) is a computable } \\
\text { representation of the physical and functional characteristics } \\
\text { of a facility and its related project/life-cycle information } \\
\text { using open industry standards to inform business decision } \\
\text { making for realizing better value }[4] \text {. }\end{array}$ & $\sqrt{ }$ & $\sqrt{ }$ \\
\hline & $\begin{array}{l}\text { General } \\
\text { Services } \\
\text { Administr } \\
\text { ation }\end{array}$ & $\begin{array}{l}\text { Building Information Modeling is the development and uses of } \\
\text { a multi-faceted computer software data model to not only } \\
\text { document a building design, but to simulate the construction } \\
\text { and operation of a new capital facility or a recapitalized } \\
\text { (modernized) facility }[5] \text {. }\end{array}$ & $\sqrt{ }$ & $\sqrt{ }$ \\
\hline BIM monograph & $\begin{array}{l}\text { BIM } \\
\text { handbook }\end{array}$ & $\begin{array}{l}\text { Building information modeling is a process facilitated by } \\
\text { digital, machine-readable record of a building, its } \\
\text { performance, its planning, its construction and later its } \\
\text { operation, therefore, BIM describes an activity, not an object } \\
\text { [6]. }\end{array}$ & $\sqrt{ }$ & $\sqrt{ }$ \\
\hline
\end{tabular}

Based on the analysis of BIM definition, some of them are from the perspective of building information model. Most of them are from the perspective of Building Information Modeling. Software developers proposed the definition of BIM mostly, part of the reason is that the company's products are BIM software, which is benefit for the sale of its products. Related influential organizations and BIM monographs, with academic and scientific nature, considering the BIM definition of the authority and comprehensive, the definition of BIM is from two perspectives. With the application of BIM technology, its influence has gone beyond its original definition, which has caused a series of changes in the production process of construction projects. So, this paper proposed BIM capabilities model is from the breadth and depth perspective.

\section{The measurement model of breadth of BIM use}

According to the definition of BIM, the BIM application breadth is based on the narrow definition of BIM, from the perspective of a technology or tool, which means BIM tool applicate scope in one 
construction enterprise. Based on the investigation of the enterprise BIM application breadth measurement method, BIM application breadth should be proportional to the number of application projects and the number of functions of each item, , which reflect the project experience of BIM application. Therefore, combining the relevant research literature [7], proposed the enterprise BIM application breadth measurement model, see formula (1).Through to industry experts interview, application case study and reference to the relevant research literature analysis, Building SMART Alliance proposed BIM application of 25 functions in project life cycle. Separately from the four aspects of the function definition, potential value, resource requirements, team capacity demand are analyzed in detail, including 14 main functions and 11 secondary functions [7]. Taking into account the potential of domestic BIM applications, this research chose to start from the 14 major BIM functions.

$$
\begin{aligned}
& \left\{\begin{array}{l}
B r_{j}=\frac{1}{14} \sum_{U=1}^{14} N_{i j} \times i \\
N_{j}=\sum_{i=1}^{14} N_{i j} \\
j \in[0,18] \\
i \in[1,14]
\end{array}\right. \\
& \text { Formula (1) }
\end{aligned}
$$

There are total 14 primary BIM uses from the BIM Project Execution Planning Guide and Templates-Version 2.0 [7].

$N_{i j}$ : the project number of i BIM uses of $\mathrm{j}$ firm.

$N_{j}$ :the total project number of BIM use in $j$ firm.

\section{The measurement model of depth of BIM use}

Based on the definition of BIM concept, BIM application depth is based on Modeling Building Information from the dynamic perspective, which is based on the project participants and the scope of BIM model data. Heesom and Mahdjoubi proposed three level of 3D/4D model application, product modeling and visualization, process modeling and analysis, collaboration and communication [8].Taylor based on the BIM application tracking survey research, identified four evolving significant BIM practice, visualization, analysis, integration, supply chain integration [9]. Succar proposed 3 stages of BIM application, object-based modelling, model-based collaboration, network-based integration [10]. Based on the existing literatures, this paper puts forward the 3 levels of BIM application depth, application and analysis based on the model, the model-based cooperation; the integration of project network, see figure 3-1. 


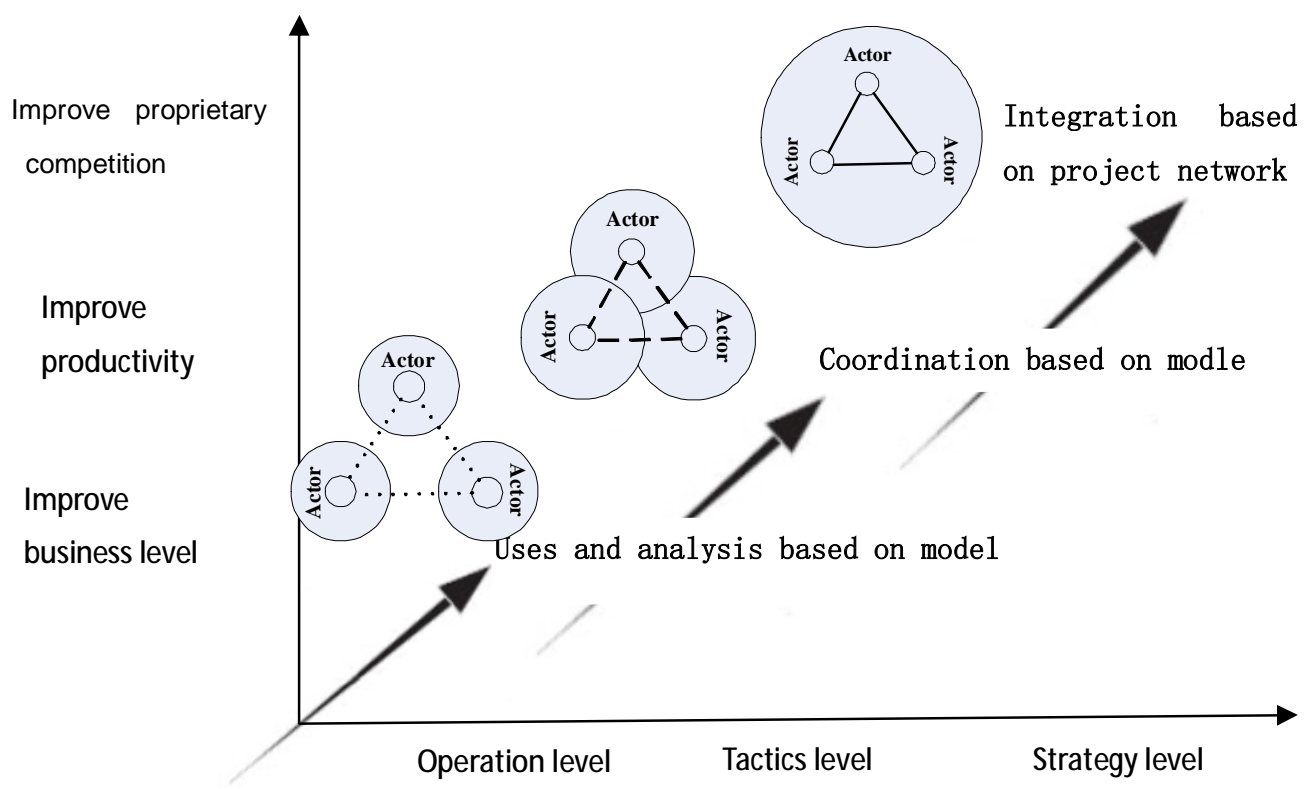

Figure 3-1

(1) Application and analysis based on Model

Application of parametric BIM software, model maker can build architure, structure and MEP model. So, project stakeholders can do clash detection, light analysis, etc. At this application level, the influence of BIM technology is limited to the organization's internal.BIM application and communication between the parties is less.

(2)The model-based cooperation

BIM is used to improve the communication and coordination among the project networks. To some extent, BIM is an inter-organization technology. At the level of application, the project team members based on the work flow of different project team members. The overall cooperation is a shallow cooperation.

(3) Integration of project network based on model

It is highest level of BIM application level, which refers to the BIM application in the project network. At the application level, BIM is a cross disciplinary $\mathrm{nD}$ model. The content is more rich and detailed, to meet the needs of the project participants in the complex analysis and application. Project stakeholders cooperate more closely based on BIM model to increase their core competitiveness and bring the project value.

\section{References}

[1] C. M. Eastman. Building product models: computer environments supporting design and construction. Boca Raton FL: CRC Press, 1999.

[2] Associated General Contractors of America (AGC).The Contractor's Guide to BIM, .1st ed. AGC Research Foundation.

[3] National Institute of Building Science (NIBS). National BIM Standard. http://cic.vtt.fi/Projeets/vbe-net/data/BIM_Slide_Show.Pdf, 2008-09-07.

[4] Facility Information Council ( FIC). Building Information Models (BIM). https://www.wbdg.org/design/bim.php/2008/4/24, 2007-12-10. 
[5] General Services Administration (GSA). GSA Mandates on Building Information Modeling. http://www.aia.org/pod_default/, 2007-12-10.

[6] Eastman C, Teicholz P, Sacks R, Liston K. BIM handbook: A guide to building information modeling for owners, managers, designers, engineers, and contractors. Hoboken: John Wiley \& Sons, 2008.

[7] The BIM Project Execution Planning Guide and Templates - Version 2.0. http://bim.psu.edu/Resources/Project/BIM_PXP-V2.0/BIM_PxP_Guide_\&_Templates_V2.0.zi p, 2011-09-01

[8] Heesom, D. and L. Mahdjoubi, Trends of 4D CAD Applications for Construction Planning [J]. Construction Management \& Economics, 2004. 22(2): p. 171.

[9] Taylor J E, Bernstein P. Paradigm trajectories of building information modeling practice in project networks [J]. Journal of Management in Engineering, 2009, 25(2): 69-76.

[10] Succar, B., Building information modelling framework: A research and delivery foundation for industry stakeholders [J]. Automation in Construction, 2009. 18(3): 357-375. 